\title{
THE OLDEST TRACES OF HUMAN SETTLEMENT IN THE VICINITY OF ULÓW IN MIDDLE ROZTOCZE (SE POLAND)
}

\author{
TADEUSZ WIŚNIEWSKI
}

A u t h o r's a d d r e s s: Institute of Archaeology, Maria Curie-Skłodowska University, Plac Marii Curie-Skłodowskiej 4, 20-031 Lublin, Poland, e-mail: tadeusz.wisniewski@poczta.umcs.lublin.pl

A b s tra c t. During the many years of archaeological research in the settlement micro-region in Ulów in Middle Roztocze, traces of human presence dated to Old and Middle Stone Ages (Palaeolithic and Mesolithic) were discovered. Most sources are flint materials, most of which lost their stratigraphic context due to subsequent settlement. At the current stage of research, their classification is possible only on the basis of a typological and comparative analysis. Most likely, the oldest traces of human occupancy in the vicinity of Ulów can be synchronized with a series of radiocarbon dating obtained for samples of charcoal from five different archaeological sites. The to-date discoveries have revealed new sources for research on the Palaeolithic and Mesolithic periods in south-eastern Poland.

K e y w o r d s: SE Poland, Middle Roztocze, Palaeolithic, Mesolithic, human settlement, flint artefacts, radiocarbon dating

\section{INTRODUCTION}

During the many years of archaeological research in the area of Ulów in Middle Roztocze, apart from the rich finds from the Neolithic, Roman and the Migration Periods, traces of much earlier settlement have also been found. They are dated back to Old and Middle Stone Ages (Palaeolithic and Mesolithic). Such dated flint artefacts were discovered on three archaeological sites (No. 3, 17, 20); the next four sites (No. 4, 20, 25, 26) provide only radiocarbon dating for charcoals that can be linked with the Palaeolithic and Mesolithic periods (NIEZABITOWSKA-WiśNIEWSKA 2017; WIŚNIEWSKI 2007).

The aim of the article is to present the findings documenting the oldest traces of the settlement discovered in the Ulów micro-region and to attempt to interpret them combined with a preliminary analysis of the radiocarbon dating. 


\section{LOCATION OF THE SITES}

Ulów, Tomaszów Lubelski District, is located at the foot of Wapielnia (385 m a.s.1.), the highest elevation of the Middle Roztocze. The village is surrounded by irregular hills cut by numerous valleys. There are quite large denivelations of the area reaching up to 30-40 m (NiEZABITOWSKA-WiŚNIEWSKA 2017; RoDZIK, NityCHORUK 2017) (Fig. 1A).
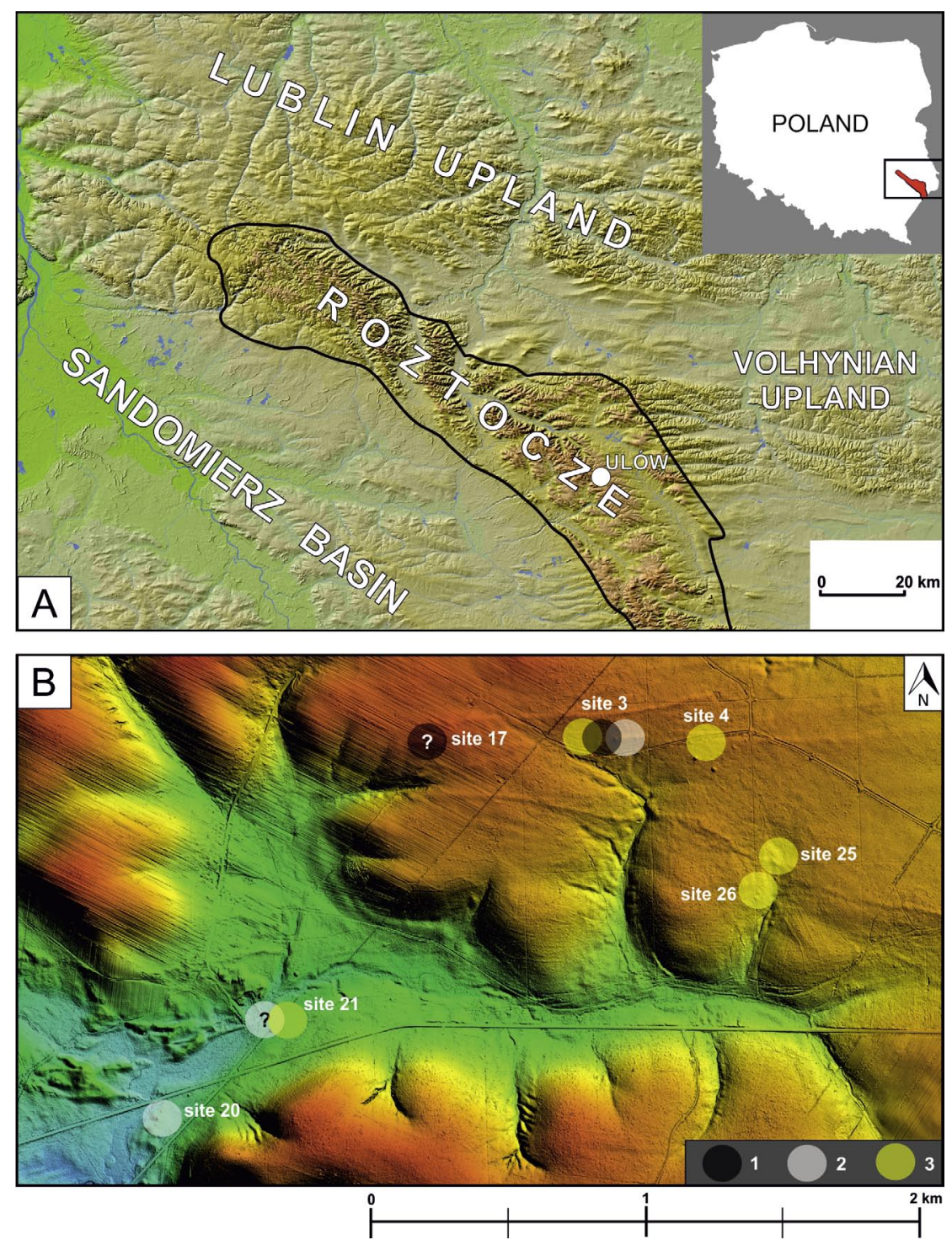

Fig. 1. A - Location of the Ulów micro-region (on the basis of the map GaWrYsiaK 2004). B - Location of sites No. 3, 4, 20, 21, 25 and 26. Legend: 1 - Palaeolithic (artefacts); 2 - Mesolithic (artefacts and probably a feature); 3 - Palaeolithic and Mesolithic radiocarbon dating 
Based on the results of archaeological research it can be determined that traces of settlement from the Palaeolithic and Mesolithic periods have been recorded within the multicultural site No. 3 (Fig. 1B). The site is located to the east of the contemporary buildings of the village, on the hilltop plateau ( $340 \mathrm{~m}$ a.s.1.) and within one of the long and narrow dunes. Approximately $70 \mathrm{~m}$ to the south from site No. 3 there is a valley of a small watercourse currently flowing only periodically (Fig. 1B).

Artefacts which, at this initial stage of the research, can also be linked to the Palaeolithic period were found at site No. 17. The site is located in the hilltop area, on the SW slope of the sandy elevation (approx. $349 \mathrm{~m}$ a.s.1.). This elevation is in the line of one of the long, narrow dunes towards W-E.

At site No. 20, located to the south of the modern buildings of the village, traces of Mesolithic settlement were discovered. The site is located on a dune at the bottom of the valley (304 m a.s.1.) (Fig. 1B).

From the next four sites only radiocarbon dating of charcoal originate, which correspond to the Late Palaeolithic and Mesolithic periods, but there were no artefacts that would date to the same period (these are sites No. 4, 21, 25, 26) (Fig. 1B). Sites No. 4, 25 and 26 are located on the hilltop ${ }^{1}$, within or in the immediate vicinity of long and narrow dunes. Site No. 21, in turn, is located on the dune at the bottom of the valley ${ }^{2}$.

In summary, the sites, on the basis of various premises, linked with the Palaeolithic and Mesolithic periods are located in two different zones - on the hilltop (No. 3, 4, $17,25,26)$ and in the bottom of the valley (No. 20, 21). Regardless of the area, all are located on the dunes. In close proximity to these sites there are also valleys of small streams.

\section{MATERIALS AND METHODS}

In the case of Ulów settlement micro-region, there are two distinct sources used to identify the oldest traces of human settlement. These are historic materials (flint and stone artefacts) and a series of radiocarbon dating.

\section{Materials}

Sources allowing identification of the oldest traces of settlement in Ulów are limited to characteristic types of flint tools and techniques for obtaining a semi-raw material for their production. Previous research did not reveal certain immovable objects. The vast majority of artefacts that can be linked with Palaeolithic and Mesolithic periods has been displaced and destroyed by the settlement of later cultures. These are, among others: Lublin-Volhynian Culture (hereinafter L-VC), Funnel Beaker Culture (hereinafter FBC), Corded Ware Culture (hereinafter CWC), Trzciniec Culture (hereinafter

\footnotetext{
1 Site No. 4 - approx. $250 \mathrm{~m}$ E from site No. 3; site No. 25 and 26 approx. $700 \mathrm{~m}$ SE from sites No. 3 and 4.

2 Approx. $520 \mathrm{~m} \mathrm{NE}$ from site No. 20.
} 
TC), Lusatian Culture (hereinafter LC) and Wielbark Culture (hereinafter WC). Traces of settlement of these cultures occur, in varying intensity throughout the area of the entire Ulów micro-region (NIEZABITOWSKA-WiŚNIEWSKA 2017). Therefore, most flint sources are mixed materials with no stratigraphic context. At the current stage of research, their classification is possible only on the basis of a typological and comparative analysis. The analysis was based on existing typological systems and studies that take into account the whole flint working for the Late Palaeolithic and Mesolithic periods of the Polish lands (SCHILD 1967, 1975; KozŁowsKi 1972, 2009; GINTER 1974; SCHILD et al. 1975).

\section{Site No. 3}

Site No. 3 in Ulów is known primarily from the remains of the cemetery from the Roman Period and the early phase of the Migration Period. In the archaeological research traces of Neolithic cultures have also been found: L-VC, FBC, CWC as well as cultures of the Bronze and Early Iron Ages: TC and LC (NiEzABitowsKaWIŚNIEWSKA 2017).

All flint artefacts (except for the items found in the pit graves under the barrows) were almost completely scattered within the excavated area of the site $\left(2236.7 \mathrm{~m}^{2}\right) .36$ artefacts were identified as linked to the oldest settlement horizon - Late Palaeolithic and Mesolithic periods ${ }^{3}$. Among them are: 6 cores, 2 willow leaf points, 23 tools and 5 pieces of flint waste being a material from tool production. At this stage of the study, no flakes or chips, except for one, were associated with these materials (see below). These groups of items were omitted due to the above-mentioned multicultural character of the finds and the lack of a stratigraphic context for most flint materials.

The collection of the Late Palaeolithic and Mesolithic artefacts consists of:

Cores -6 items; one single platform blade core (Fig. 2: 1), the remaining ones are single platform cores with changed orientation (Fig. 2: 3-7); flaking surfaces are rounded or flat; early core preparation is limited to remove core tablet; in some cases cores are characterized by detachment of flakes from their distal parts - it was a repair treatment, shaping the tip of the core and enabling further exploitation of flaking surfaces (Fig. 2: 1, 4, 5); cores are in the final stage of exploitation or residual; all made of small pebbles or slightly larger lumps of erratic Baltic flint; dimensions: the length of the largest piece does not exceed $30 \mathrm{~mm}$, width $28 \mathrm{~mm}$ and thickness $21 \mathrm{~mm}^{4}$;

End-scrapers - 11 items; all flake-like, stocky and short (Fig. 3: 4-12); 1 item with retouched edge (Fig. 3: 8), four with both retouched edges (Fig. 3: 5, 6, 9, 10), the other two of double variation (Fig. 3: 5); scraping surfaces are rounded (Fig. 3:

\footnotetext{
3 In addition to flint artefacts from the Palaeolithic and Mesolithic periods, several hundred other flint artefacts were found at site No. 3. On the basis of a typological and technical analysis, it was considered more likely that they belong to the younger cultures of the Neolithic and Bronze Age. Their detailed discussion goes far beyond the scope of this article.

4 Dimensions will be given in millimeters in the following order: maximum length, width and thickness.
} 

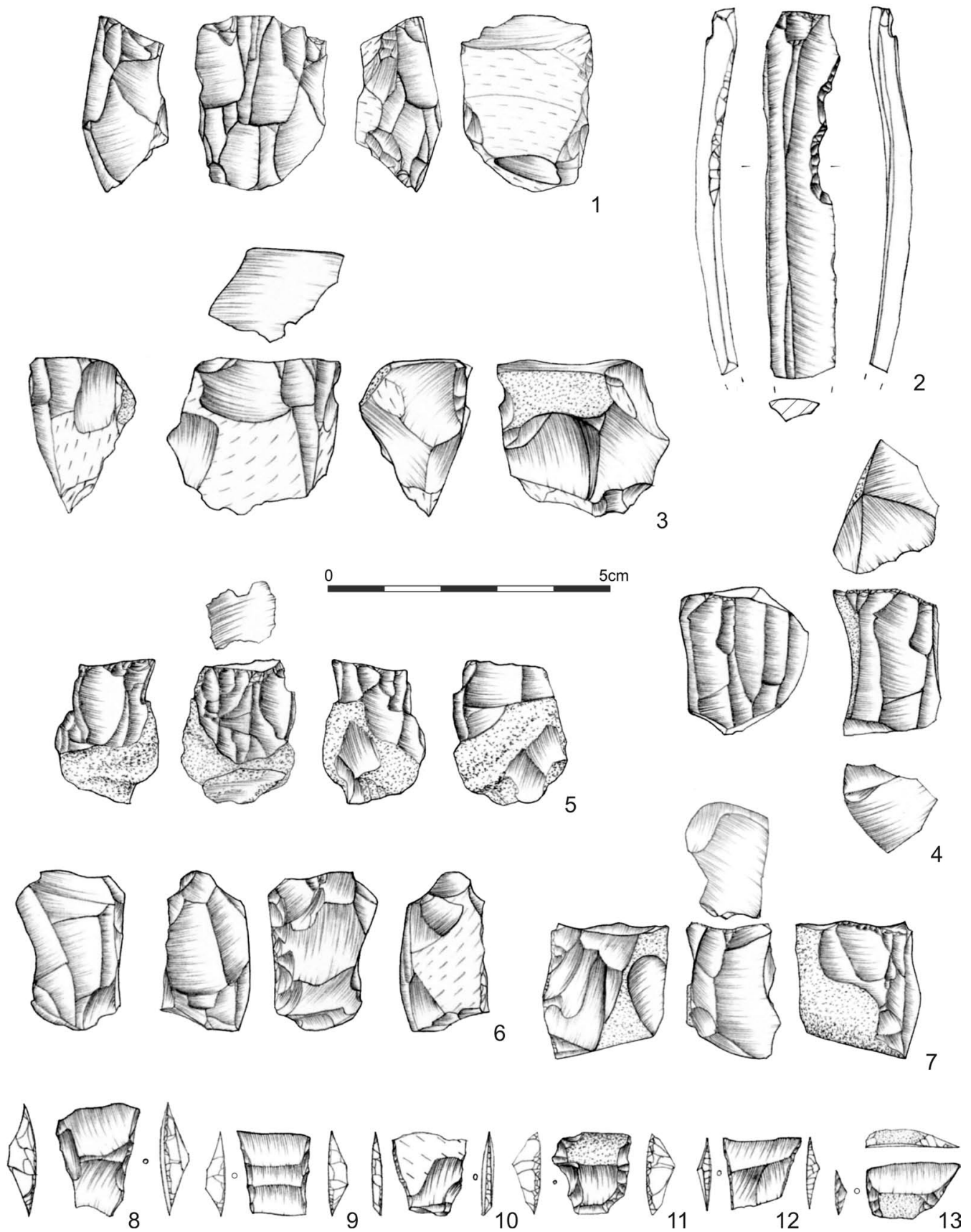

Fig. 2. Ulów, site No. 3. 1, 3-7: cores; 2: retouched blade (wiór przedrylcowczy); 8-13: trapezes

$4,6,7,9-11$ ) or rounded - oblique (Fig. 3: 8, 12); in the case of 9 end-scrapers, the raw material was referred to as erratic Baltic flint (?), 2 others unidentified (strongly burnt); dimensions within the ranges: $13-32 \times 15-29 \times 5-10$; 

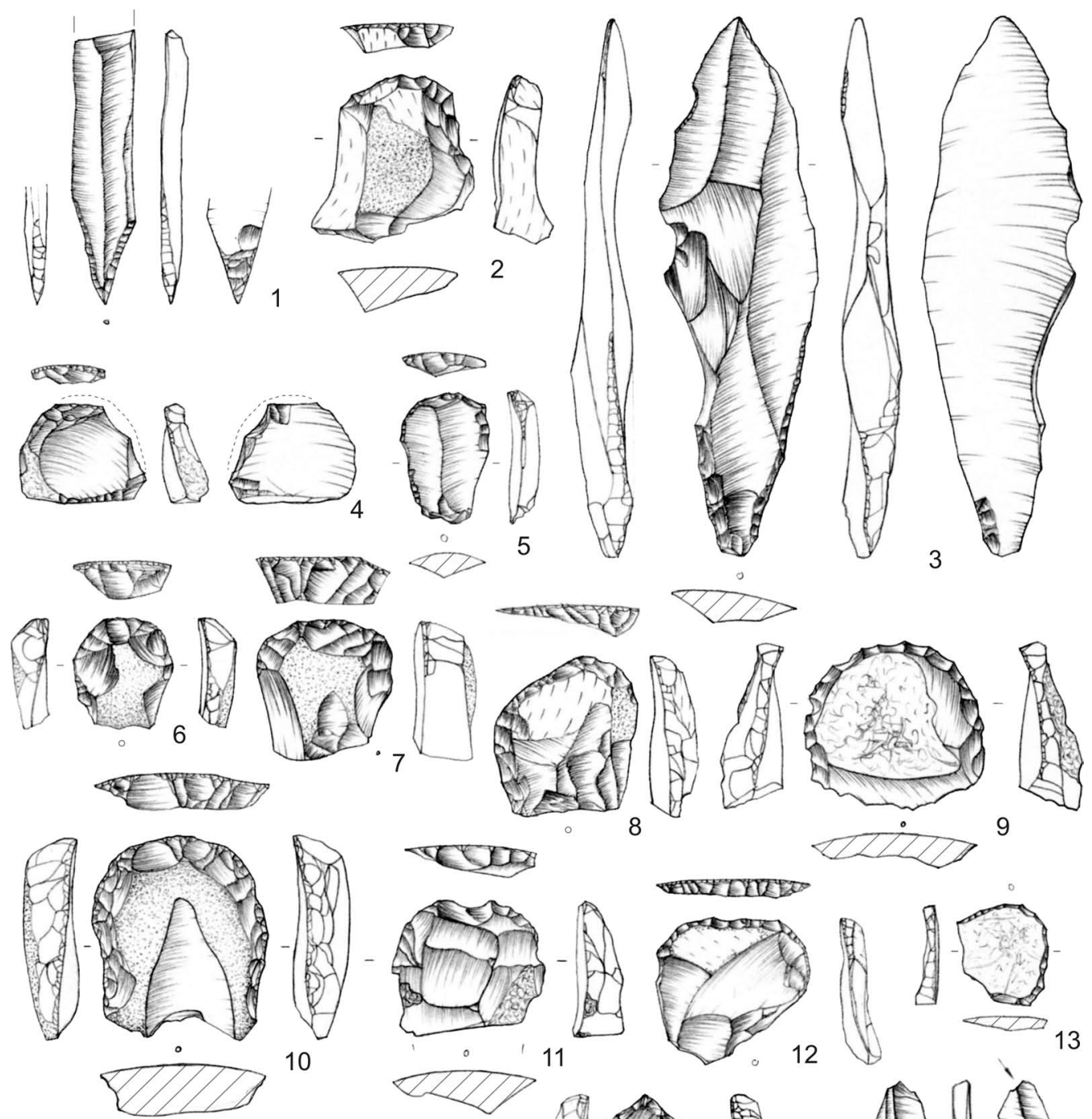
11
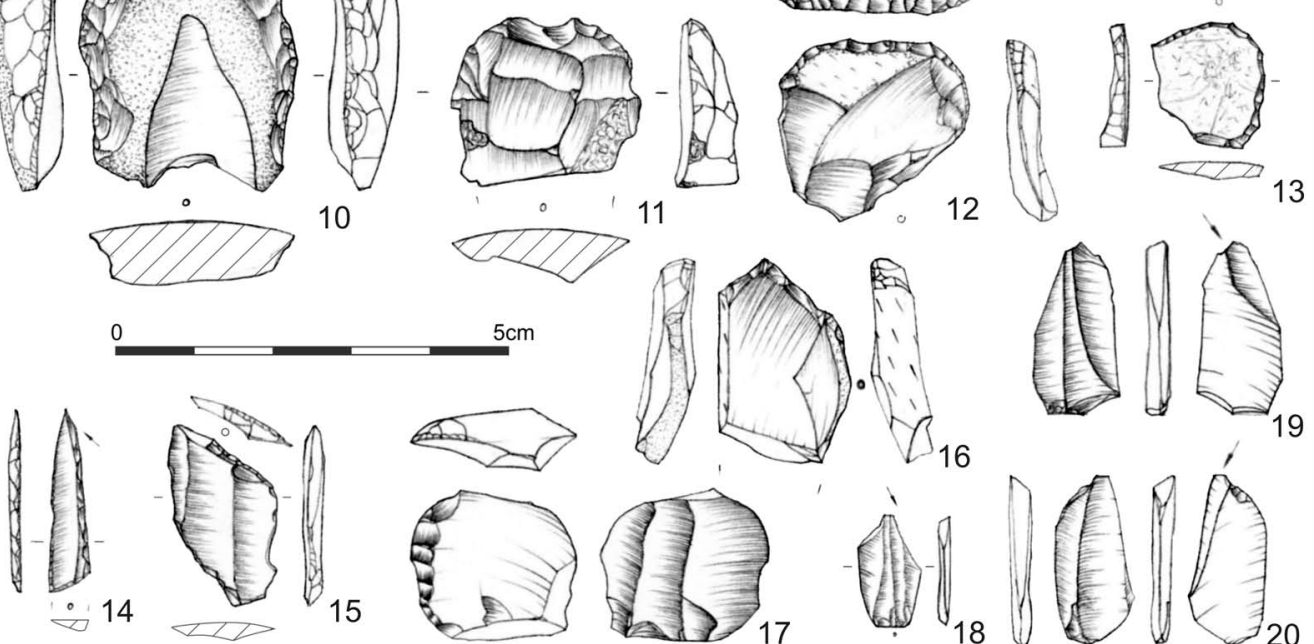

Fig. 3. Ulów, site No. 3. 1, 3: willow leaf points; 2, 4, 13, 16, 17: scrapers; 5-12: end-scrapers; 14: triangle; 15: rhomb; 18-20: microburins 
Scrapers -4 items; 3 one-sided (Fig. 3: 2, 16, 17; 4: 1), including 1 with retouched one edge on ventral side (Fig. 3: 17); made of erratic Baltic flint; 1 item unidentified (burnt and heavily damaged; Fig. 3: 13); dimensions: 17-26 × 14-27 × 4-7;

Trapezes -6 items; two types (according to S.K. KozŁowsKI): AC -3 items (Fig. 2: 8-10) and BJ - 3 items (Fig. 2: 11-13); 4 made of erratic Baltic flint, 2 of chocolate flint; dimensions AC: $13-15 \times 15-20 \times 2-5$; dimensions BJ: $14-17 \times 10-14 \times 2-5$;

Triangle TE - rectangular, with a slight retouch of the third edge; made of erratic Baltic flint; dimensions: $24 \times 6 \times 2$ (Fig. 3: 14; 4: 4);

Rhomb BW - made of erratic Baltic flint; dimensions $23 \times 13 \times 3$ (Fig. 3: 15);

Microburins - 5 items; all of them from the proximal parts of blades, so-called ordinary microburins (Fig. 3: 18-20; 4: 5); 4 made of erratic Baltic flint, 1 from Świeciechów flint; dimensions: $14-22 \times 8-13 \times 2-3$;
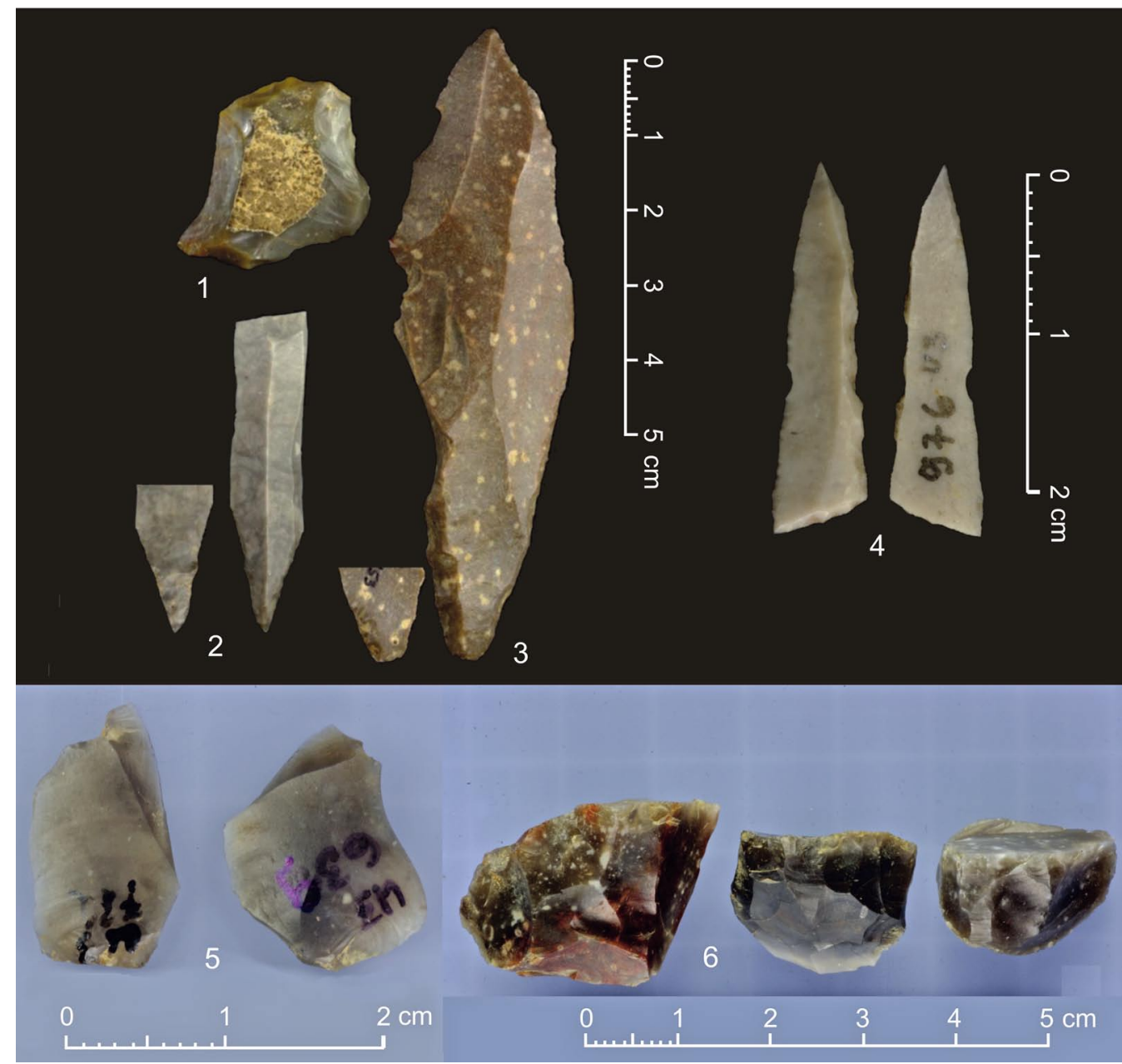

Fig. 4. Ulów, site No. 3. 1: scraper; 2, 3: willow leaf points; 4: triangle; 5: microburins; 6: cores 
Retouched blade - (according to R. SCHILD et al. 1975: 31 - wiór przedrylcowczy) - proximal part, the right edge of the blade has two retouched niches; removed from single platform core; slightly curved, broken in the distal part; made of erratic Baltic flint; dimensions: $65 \times 13 \times 4$ (Fig. 2: 2);

Willow leaf points -2 items; Masovian-type with a broken tip, made of erratic Baltic flint (?), dimensions: $43 \times 10 \times 3$ (Fig. 3: 1; 4: 2); a massive Masovian-type from the Świeciechów flint, dimensions: $85 \times 25 \times 9$ (Fig. 3: 3; 4: 3).

\section{Site No. 17}

During several surface surveys of site No. 17 in Ulów, a large inventory of artefacts made of crystalline rocks (quartzites and quartzite sandstones) ${ }^{5}$ was collected. In total, there are 804 elements, among these: 18 tools, 2 cores, 402 flakes and 383 chunks. Among the tools, forms most closely resembling side-scrapers (Fig. 5: 1-2) and unifacial knives are predominant (Fig. 6). A large series of massive flakes were obtained by means of a direct percussion with a hard, stone hammer. This is confirmed by the massive butts and numerous bulb scars on the ventral side of flakes. The two highlighted cores resemble discoidal forms with double-sided processing (Fig. 5: 3, 4) (WIŚNIEWSKI 2012). The entire inventory is very difficult to interpret and at the present stage of research it is not easy to clearly indicate its chronological and cultural affiliation. It seems, however, that these materials can be associated with traces of settlement from the Late Middle Palaeolithic / Early Upper Palaeolithic (approx. 40000 years old).

Apart from the materials from crystalline rocks found at site No. 17, as a result of surface surveys and excavation research, the remains of the FBC settlement were discovered (about two thousands fragments of pottery). The surface surveys showed also isolated fragments of pottery (2 fragments), which may be linked to Bronze Age (LC) and the Roman Period (WC) (NieZabitowsKa-WiśniewsKa 2017).

\section{Site No. 20}

Flint artefacts were discovered during the exploration of two barrows belonging to the CWC. These artefacts were placed in the illuvial levels of the podzolic soil, outside the mounds and burial pits. The inventory consists of:

Cores - 6 items; all are from single platform blade - flake cores in the final stage of exploitation; among them, two items with changed orientation; flaking surfaces are rounded or flat; on one item there are visible traces of the preparation of the back side of the core; all made of small pebbles of erratic Baltic flint; dimensions: 13-32 $\times 16-25 \times 11-27$ (Fig. 4: 6);

Double end-scraper - stocky with rounded and diagonal scraping surfaces; made of erratic Baltic flint; dimensions: $33 \times 17 \times 10$;

5 The material was kindly consulted by professor Bolesław Ginter and professor Jerzy Libera. 


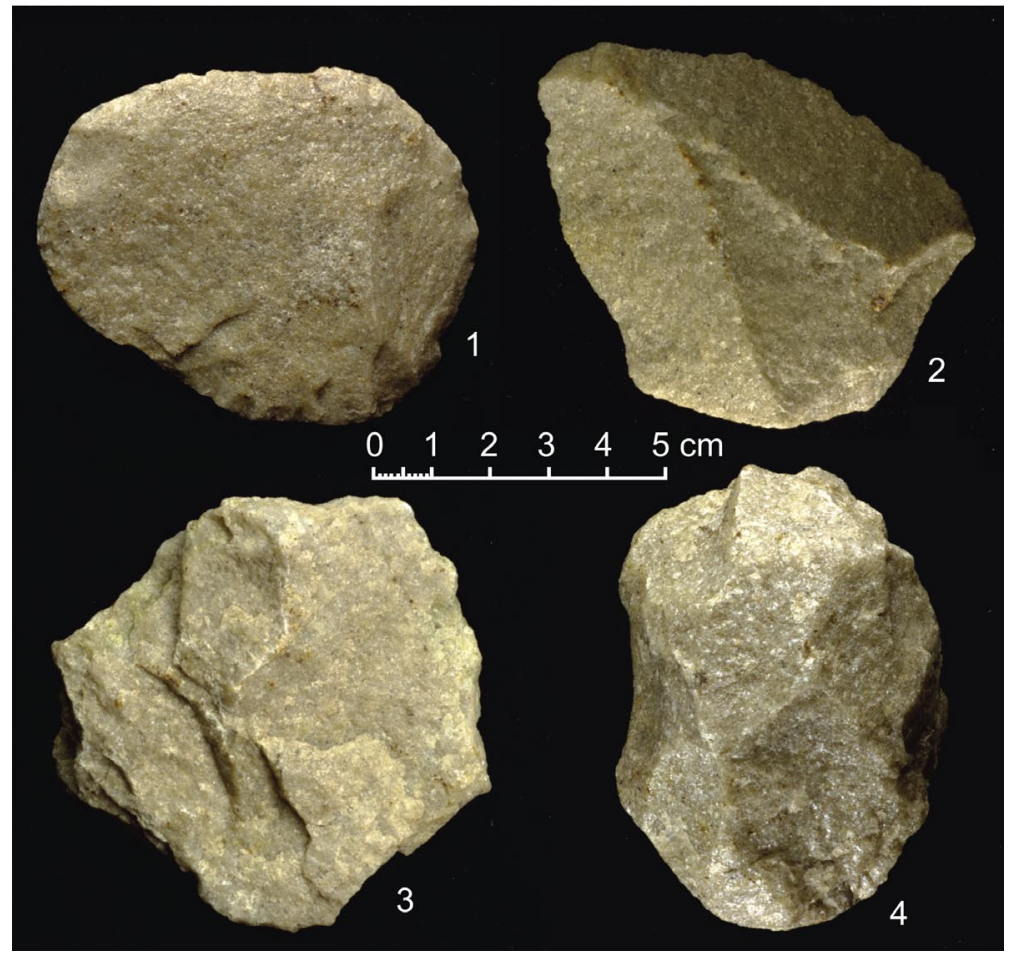

Fig. 5. Ulów, site No. 17. 1, 2: side-scraper-like tools; 3, 4: cores

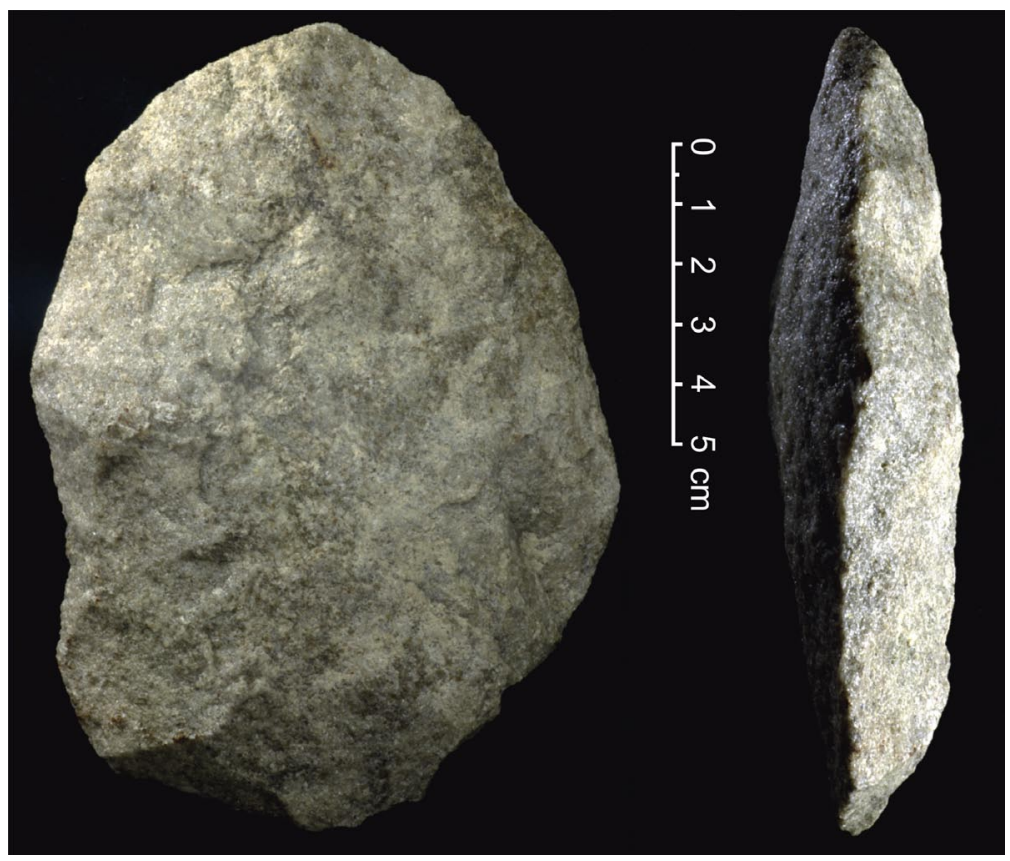

Fig. 6. Ulów, site No. 17. Unifacial knife-like tool 
Double scraper - made of erratic Baltic flint; dimensions: $27 \times 14 \times 6$;

Backed bladelet - proximal fragment with partially retouched on the right edge; made of erratic Baltic flint; dimensions: $12 \times 12 \times 2$;

Blade - removed from single platform core; burnt (unidentified raw material); dimensions: $47 \times 12 \times 3$;

Flake - partially cortical flake, made of erratic Baltic flint; dimensions: $19 \times 21 \times 9$.

\section{Radiocarbon dating}

In recent years, during the implementation of the research project "Roztocze the ancient terra incognita? ..." a series of 90 radiocarbon datings of charcoal samples were made (Moskal-DEL Hoyo et al. 2017; NieZABITOWSKA-WiśNIEWSKa 2017). Among the results obtained, dating of eight samples significantly differs from the others, indicating the possibility of linking them with the Palaeolithic and Mesolithic periods (Tab. 1).

The oldest of the radiocarbon dating obtained in the Ulów micro-region comes from site No. 26 and was taken from charcoal found in the central grave under the CWC barrow No. 1. It can be time-stamped between 11490 and 11341 BC (68.2\% probability $)^{6}$. With all certainty it cannot be linked with the CWC grave. The presence of a charcoal with such dating can only be explained by the digging of the grave into a much older layers. Thus, it should be recognized that the charcoal itself was in the secondary deposit.

Among the radiocarbon dating from site No. 4 (Fig. 1B), located approx. $250 \mathrm{~m} \mathrm{E}$ from site No. 3, three dating can be linked with the settlement phase examined by this article. They were taken from charcoals found within the central perimeter of the central pit grave under barrow No. 2 of the CWC (within the reddish layer surrounding the burial pit) and from the bottom part of burial pit (a piece of charcoal was found next to a flint axe belonging to the CWC). Preliminary findings indicate that these dates may be related to the fact that the central burial pit was digged into paleosol with charcoal (Tab. 1). Traces of similar paleosol have been observed in geological surveys at site No. 9 .

Two radiocarbon dating obtained from site No. 3 (features No. 66 and 74) can be indirectly linked with the oldest settlement (horizon 0 on site No. 3 - MosKaL-DEL Hoyo et al. 2017). Both of these features were considered to be the graves belonging to the $\mathrm{WC}$ as evidenced by their shapes, the nature of the fillings and found artefacts. Additionally, within object No. 74 two microburins connected with the Mesolithic period were also found (Fig. 4: 5). In this context and at the current stage of the research, it can be assumed that the dates obtained are related to the fact that features from the Roman Period were embed in older, Mesolithic layers or that the dated charcoals were found on the secondary context.

A single radiocarbon dating corresponding to the Mesolithic period was obtained for a charcoal found in the CWC grave at site No. 25. Most probably, the grave was

${ }^{6}$ Calibrated radiocarbon ages (cal BC) were obtained based on the IntCal13 radiocarbon calibration dataset (ReIMER et al. 2013) and the OxCal 4.2 calibration software (Bronk Ramsey 2009). See also Table I. 


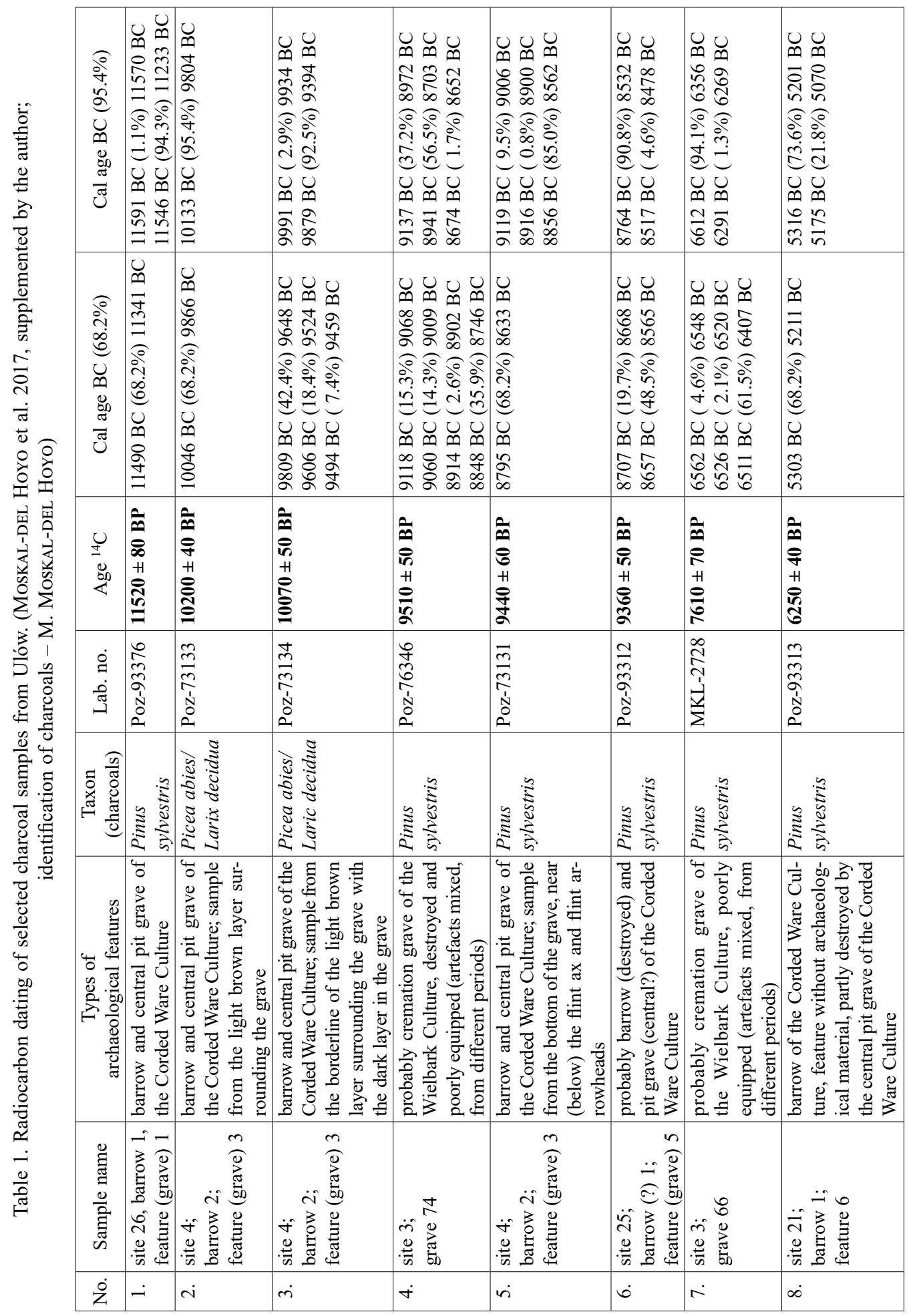


originally covered by a mound. The dated charcoal was found in the bottom part of burial pit. Similarly as in the case of dating from sites No. 4 and 26, it originated in a secondary deposit.

One radiocarbon dating that can be linked with the Mesolithic period comes from site No. 21, located on the dune at the bottom of the valley (Fig. 1B). The dating was obtained for a charcoal sample taken from feature No. 6 located under the CWC barrow. The object itself was characterized by a very high charcoal content in the filling, in the absence of artefacts. It has also been partially disturbed by the CWC central grave.

\section{DISCUSSION}

Basing on the current state of research, probably the oldest remnants of human presence in the Ulów micro-region can be found at site No. 17. The artefact from crystalline rocks and their preliminary selection in each artefact category leave many questions and doubts. The research can be considered problematic to interpret both in terms of typological classification as well as the raw material used to make them. In the regional range (SE Poland) there are no analogical finds to the described inventory. It cannot be ruled out, however, that these are materials from the Early Upper Palaeolithic or Late Middle Palaeolithic (about 40000 years old). So far, it is known that the site is located on aeolian sands, which developed intensively in the lower and middle Pleniglacial (73000-44000 years ago) (BuraCZYŃSKi 1993: 16). Possibly, this issue will be somewhat approximated after completing the series of luminescence dating (OSL) of sediments in the site and linking their results with geological observations.

The multicultural character of the site No. 3 does not allow to unambiguously assign most of the flint artefacts to any specific cultural units. As already mentioned, during the archaeological research traces of the Neolithic, Bronze Age and Early Iron Age cultures as well as the Roman Period and the early phase of the Migration Period settlement were also found there. Thus, most of the materials lost the stratigraphic context as a result of the subsequent settlement phases. Due to the mixed character of the flint inventory it must also be taken into account that some of the types of artefacts discovered there may have been parts of the inventories of other cultures that resided there or the artefacts themselves might have been re-used.

Two Masovian-type willow leaf points discovered at site No. 3 would suggest a link to the Late Palaeolithic (Swiderian Culture). The youngest sets containing this type of artefacts in Poland, based on radiocarbon research, are dated to Younger Dryas (GS-1) and early Preboreal (12930-12571 cal BP; 12747-12391 cal BP) ${ }^{7}$ (SOBKowIAKTABAKA 2016: 205, 206).

The remaining, presented above flint materials from site No. 3 can be connected with the Mesolithic period. All the cores (Fig. 2: 1, 3-7), end-scrapers (Fig. 3: 4-12),

\footnotetext{
7 These refer to the VI level from the site in Całowanie, especially Peat Trench X/83, Bed 9b (10140 $\pm 80 \mathrm{BP}-\mathrm{Gd}$ 1648) and Peat Trench III, Bed 9a (9935 \pm 110 BP - GrN-5254) - (SCHILD 2014: 30, Table II).
} 
scrapers (Fig. 3: 2, 16, 17) as well as other artefacts described above find their counterparts in other Mesolithic inventories found in Poland. Trapezes AC and BJ (Fig. 2: 8-13) are connected with the late Mesolithic (KozŁowsKI 2009). The single rhomb BW can also be associated with the analogical late Mesolithic materials - (Fig. 3: 15). It can also be a trace of unspecified activities from the East, which had been already presented before to SE Poland (KozlowsKi 1985: 20, 21; Libera 1995: 51). For the late Mesolithic we can ascribe the single triangle TE (Fig. 3: 14; 4: 4). S.K. KozŁowsKI (2009: 185) puts the forms in in the second half/at the end of the 8th millennium cal BC (approx. 9500-9000 BP) and connects them with the so-called Post-Maglemosian ((Post) Maglemosian-Chojnice-Pieńki) (KozŁowski 2009: 361).

In the Roztocze region, as well as the surrounding areas there are only single artefacts (stray finds), that can be associated with the Late Middle Palaeolithic / Early Upper Palaeolithic. Among them are: retouched flake from Werchrata (Horyniec-Zdrój commune), a side-scraper found in Nowy Machnów (Lubycza Królewska commune) (Gurba, Libera 2011: 46, fig. 8b) or bifacial knife from Opaka (Lubaczów commune) (PILCH 2000). The villages are located approx. $40 \mathrm{~km}$ from Ulów.

Traces of the Late Palaeolithic and Mesolithic settlements were also discovered a short distance from Ulów. They come from sites in Jeziernia (Tomaszów Lubelski commune), Żurawce (Lubycza Królewska commune), Tarnawatka (local commune) and Chlewiska (Narol commune) (Libera 1998: 84, 87, 93; 2005; Gurba, Libera 2011). Apart from the Early Mesolithic artefacts discovered during the excavation research in Chlewiska (TALAR 1973), the remaining inventories are few in numbers and, to a large extent, accidental finds. Nevertheless, from the point of view of the location of sites, it is important to note that these materials come from dune sites, similar to those in Ulów.

The late Pleistocene and early Holocene radiocarbon dating described above are without a doubt in the chronology of the Late Palaeolithic and Mesolithic (Tab. 1). The context of the discovery of such radiocarbon dated charcoals also reflects the complexity and difficulty in interpreting the oldest settlement traces in Ulów, most often affected or destroyed by the settlement of later cultures, mainly the CWC and WC.

It is also interesting to find that a large part of the charcoals for which the radiocarbon dating were obtained in context of the CWC barrows. All of the burial mounds on the hilltop plateau (site No. $4,25,26$ ) were erected directly on or in close proximity to the long, narrow dunes. At the present stage of research it can be only determined that the CWC population, by digging up burial pits, sometimes as deep as $2 \mathrm{~m}$ from the surface, had to dig into much older layers. As already mentioned, similar paleosol was recorded in a trench within a long dune at site No. 9. At the moment, it is difficult to address the nature of the presence of charcoals in this layer. It is possible that they are related to a forest fire in the late Pleistocene / Early Holocene. However, it cannot be unequivocally determined whether it came to be as a result of natural causes or if it is related to human activity. It should also be kept in mind that that the willow leaf points of the Swiderian Culture from the site No. 3 were found next to the CWC barrow located on one of the dunes. In this context, it is very cautious to assume that at least 
some of the radiocarbon dating obtained for similarly located sites in the upland area of Ulów micro-region should be associated with an unspecified human activity.

The radiocarbon dating from feature No. 6 at site No. 21, allowing to link it with the Mesolithic period. On the neighbouring site No. 20, such dated artefacts were discovered. The location of both of these sites on the dunes at the bottom of the same valley perfectly fits into the canons of other Mesolithic settlements known in other areas of Poland. Interestingly, both Mesolithic flint materials (site No. 20) and the radiocarbon dated feature (site No. 21) were discovered during the excavation of the CWC barrows. The stratigraphic relations observed in both these cases allow us to state that burial mounds and / or the CWC objects have violated and partially destroyed older, Mesolithic cultural layers or features.

\section{CONCLUSIONS}

Many years of research within the complex of archaeological sites in Ulów revealed new sources for research on the Palaeolithic and Mesolithic periods in south-eastern Poland. Currently, several phases of the oldest settlement can be distinguished: perhaps the Late Middle Palaeolithic / Early Upper Palaeolithic, Late Palaeolithic and Late Mesolithic. Available sources only points to existence of such dated settlements. The previous discoveries, however, represent a promising prospect for further exploration of the Palaeolithic and Mesolithic settlement in the micro-region of Ulów in Middle Roztocze.

Acknowledgements. The work was funded by the National Science Centre (Poland) allocated for the project based on the decision number DEC-2013/09/B/HS3/03352.

\section{SUMMARY}

During the many years of archaeological research in the area of Ulów in Middle Roztocze, apart from the rich finds from the Neolithic, Roman and the Migration Periods, traces of much earlier settlement have also been found. They are dated back to Old and Middle Stone Ages (Palaeolithic and Mesolithic). Such dated flint artefacts were discovered on three archaeological sites (No. 3, 17 and 20); the next four sites (No. 4, 20, 25 and 26) provide only radiocarbon dating for charcoals that can be linked with the Palaeolithic and Mesolithic periods. The sites are located in two different zones - on the hilltop (No. 3, 4, 17, 25 and 26) and in the bottom of the valley (No. 20, 21). Regardless of the area, all are located on the dunes. In close proximity to these sites there are also valleys of small streams.

The vast majority of artefacts that can be linked with the Palaeolithic and Mesolithic periods has been displaced and destroyed by the settlement of later cultures (from the Neolithic, Bronze Age and Early Iron Age). The context of the discovery of such radiocarbon dated charcoals also reflects the complexity and difficulty in interpreting the oldest settlement traces in Ulów.

Many years of research within the complex of archaeological sites in Ulów revealed new sources for research on the Palaeolithic and Mesolithic periods in south-eastern Poland. Currently, several phases of the oldest settlement can be distinguished: perhaps the Late Middle Palaeolithic / Early Upper Palaeolithic, Late Palaeolithic and Late Mesolithic. Available sources only points to existence of such dated settlements. 


\section{REFERENCES}

Bronk Ramsey C., 2009. Bayesian analysis of radiocarbon dates. Radiocarbon 51(1): 337-360.

BuRACZYŃSKi J., 1993. Rozwój procesów eolicznych piętra Wisły na Roztoczu i w Kotlinie Sandomierskiej. Lublin. In Polish.

GaWrysiak L., 2004. Województwo lubelskie - cieniowana mapa rzeźby. Polskie Towarzystwo Geograficzne, Lublin. In Polish.

GinTER B., 1974. Wydobywanie, przetwórstwo i dystrybucja surowców i wyrobów krzemiennych w schyłkowym paleolicie Północnej części Europy środkowej. Przegląd Archeologiczny 22: 5-122. In Polish with English summary.

Gurba J., Libera J., 2011. W pradziejach. In: BuraczyŃSKi J., Roztocze, dzieje osadnictwa. Lublin: 37-73. In Polish.

Kozıowski S.K., 1972. Pradzieje ziem polskich od IX do V tysiąclecia p.n.e. Warszawa. In Polish with English summary.

KozŁowski S.K., 1985. Pontic elements in the Mesolithic of south-eastern Poland. In: KoKowsKi A. (Ed.), Memoires Archeologiques. Lublin: 19-26.

Kozıowski S.K., 2009. Thinking Mesolithic. Oxbow Books. Oxford, UK.

Libera J., 1995. Późny paleolit i mezolit środkowowschodniej Polski. Część pierwsza. Analiza. Lubelskie Materiały Archeologiczne tom IX. Lublin. In Polish with summary.

Libera J., 1998. Późny paleolit i mezolit środkowowschodniej Polski. Część druga. Źródła. Lubelskie Materiały Archeologiczne tom XI. Lublin. In Polish with summary.

Libera J., 2005. Od łowców mamutów do pierwszych pasterzy, In: Banasiewicz-SzyKula E. (Ed.), Archeologia Roztocza. Krajobraz przyrodniczo - kulturowy. Lublin: 21-46. In Polish.

Moskal-Del Hoyo M., Krąiec M., Niezabitowska-Wiśniewska B., 2017. The chronology of site 3 in Ulów (Tomaszów Lubelski district, east Poland): the relevance of anthracological analysis for radiocarbon dating at a multicultural site. Radiocarbon 59(5): 1399-1413.

NieZABITOWSKA-WiŚNIEWSKA B., 2017. Archaeological research results of the settlement micro-region in the area of Ulów in Middle Roztocze in the light of the project "Roztocze - the ancient terra incognita?...". Folia Quaternaria 85: 5-47.

PILCH A., 2000. Najstarsze zabytki archeologiczne w zbiorach Muzeum w Lubaczowie, Rocznik Lubaczowski IX-X: 196-199. In Polish.

Reimer P. J., Bard E., Bayliss A., Beck J. W., Blackwell P. G., Bronk Ramsey C., Buck Ce., Cheng H., Edwards R. L., Friedrich M., Grootes P. M., Guilderson T. P., Haflidason H., Hajdas I., Hatté C., Heaton T. J., Hoffmann D. L., Hogg A. G., Hughen K. A., Kaiser K. F., Kromer B., Manning S. W., Niu M., Reimer R. W., Richards D. A., Scott E. M., Southon J. R., Staff R. A., Turney C., VAN Der Plicht J., 2013. Intcal13 and Marine13 radiocarbon age calibration curves 0-50,000 years cal BP. Radiocarbon 55(4): 1869-1887.

Rodzik J., NitychoruK J., 2017. Abiotic environmental conditions of former settlement in the vicinity of Ulów in Roztocze (SE Poland). Folia Quaternaria 85: 65-79.

Schild R., 1967. Wieloprzemysłowe stanowisko Rydno IV/57 (Grzybowa Góra, pow. Starachowice), In: Materiały do prahistorii plejstocenu i wczesnego holocenu Polski. Wrocław-Warszawa-Kraków: 124-208. In Polish with English summary.

SCHILD R., 1975. Późny paleolit, In: Prahistoria ziem polskich, t. I. Wrocław-Warszawa-Kraków-Gdańsk: 159-338. In Polish. 
Schild R., 2014. Geomorphology, stratigraphy, paleoecology and radiochronology. In: ScHILD R. (Ed.), Całowanie. A Final Paleolithic and Early Mesolithic site on an Island in the Ancient Vistula Channel. Warsaw: 17-58.

Schild R., Marczak M., Królik H., 1975. Późny Mezolit. Próba wieloaspektowej analizy otwartych stanowisk piaskowych. Wrocław-Warszawa-Kraków-Gdańsk. In Polish with English summary.

Sobkowiak-TABaka I., 2016. The last Late Glacial hunter-gatherers. In: UrbańczyK P. (Ed.), The Past Societes. Polish Lands from the first evidence of human presence to the Early Middle Ages. 1, 500,000 -5,500 BC, J. Kabaciński (Ed.). Warszawa: 199-228.

Talar A., 1973. Wczesnomezolityczne stanowisko w Chlewiskach, pow. Lubaczów. Materiały i Sprawozdania Rzeszowskiego Ośrodka Archeologicznego za lata 1968-1969. Rzeszów: 159-161. In Polish.

WiśNiewski A., 2012. Przejawy zachowań technologicznych ludzi u schyłku plejstocenu środkowego. Przykłady z Europy Środkowej. Wrocław. In Polish with English summary.

WiŚNIEWSKi T., 2007. Zanim przybyli Germanie. In: NiEZABITOWSKA-WiśNIEwsKa B., Ulów - tajemnica starożytnego Roztocza (katalog wystawy). Lublin: 39-48. In Polish. 